\title{
One big science project or 1000 smaller ones?
}

\author{
Shelia X. Wei, Howell Y. Wang, Cong Cao* and Fred Y. Ye* \\ Historical experiences show that big science projects such as Manhattan, Apollo, LHC and the \\ Human Genome Project often need large investment and inevitably consume significant socio- \\ economic resources, whereas small science projects need only small investment. While most big \\ science projects are based on known scientific principles, smaller ones explore unknowns that may \\ result in breakthroughs, some of which may lead to Nobel Prizes. Closing one big science project \\ may afford 1000 small science projects quantitatively. As such, decision-making on a big science \\ project is not only a scientific issue, but also a socio-economic one. Based on the cost-benefit anal- \\ ysis of LHC (big science) and CNAO (small science), we found that small science projects have a \\ higher benefit/cost ratio. At least three policy effects need to be considered: (1) Decision on invest- \\ ing in a big science project should consider both scientific and socio-economic merits. (2) Small \\ science projects could be more effective than bigger ones in exploring the scientific frontier. (3) \\ Replacing one big science project with many small science ones might benefit the scientific enter- \\ prise.
}

Keywords: Big and small science, Nobel Prize, cost-benefit analysis, socio-economic merits.

SINCE Price ${ }^{1}$ published his book, Little Science, Big Science and ... beyond in 1963, governments worldwide have spent tremendous amounts of resources supporting the endeavour of big science that explores both the unknown world and the reality ${ }^{2}$. However, while human knowledge has been rapidly accumulating, some big science projects are technical in nature utilizing or integrating applications based on known scientific principles, thus departing from their original purposes of exploring the unknown world.

Recently, Chinese physicists have been heatedly debating whether China should build a Circular ElectronPositron Collider (CEPC) ${ }^{3-5}$. On 16 June 2016, the Institute of High Energy Physics of the Chinese Academy of Sciences received a funding of 36 million yuan (US\$ 5.5 million) from the Ministry of Science and Technology to start preliminary research on the construction of CEPC. Chen Ning Yang, a Chinese-origin Nobel Prize winner in physics, strongly opposed the project. Among the reasons why China should not go ahead with such a project now is the astronomical cost, which, estimated to be US\$20 billion, if not more, may squeeze expenditure for other scientific research projects and affect people's livelihood.

Shelia X. Wei, Howell Y. Wang and Fred Y. Ye are in the International Joint Informatics Laboratory and Jiangsu Key Laboratory of Data Engineering and Knowledge Service, School of Information Management, Nanjing University, Nanjing 210023, China and Cong Cao is in the Nottingham University Business School (China), University of Nottingham Ningbo China, Ningbo 315100, China.

*For correspondence. (e-mail: cong.cao@nottingham.edu.cn; yye@nju.edu.cn)
While Yang has been consistent in his attitude towards high energy physics experiments, issues at stake go beyond the costly big science project itself. In fact, the project, and big science projects in general, concern not only the scientific community but also ordinary citizens and are worthy of a general discussion.

\section{Small science: great achievements with small investment}

A great number of important discoveries have come from small teams of investigators through the approach of small science, where small investment produces great achievements ${ }^{6}$. Several Nobel Prizes have been awarded with the winning scientists doing research driven by personal interests and supported by small grants. Table 1 shows five representative Nobel Prize-winning achievements in physics, chemistry and medicine that may be categorized as small science.

The representative examples in Table 1 show that grants of small science projects leading to Nobel Prizes are in million of US dollars.

\section{Big science: great achievements with big investment}

Alvin Weinberg, a physicist at the Oak Ridge National Laboratory, USA, coined the term 'big science' in 1961 in a Science article titled 'Impact of large-scale science on the United States'. He described big science as part of 
Table 1. Some representative Nobel Prizes as achievements of small science

\begin{tabular}{|c|c|c|c|c|c|}
\hline Field & Project & $\begin{array}{l}\text { Possible grants } \\
\text { (US\$, except for the first) }\end{array}$ & $\begin{array}{c}\text { Possible grants } \\
\text { (converted to } 2019 \text { US\$) }\end{array}$ & Award year & Funding period* \\
\hline Physics & Discovery of pulsars & $17,286 £$ & 404,731 & $1974^{\mathrm{a}}$ & $1965-67$ \\
\hline Chemistry & Study of ribosome structure/function & $2,235,915$ & $3,318,671$ & $2009^{\mathrm{b}}$ & $1985-2000$ \\
\hline Chemistry & $\begin{array}{l}\text { Molecular study of potassium channel } \\
\text { function }\end{array}$ & $1,849,032$ & $2,989,141$ & $2003^{b}$ & $1990-98$ \\
\hline Medicine & $\begin{array}{l}\text { Introducing specific gene modifications in } \\
\text { mice by the use of embryonic stem cells }\end{array}$ & $2,867,247$ & $5,546,356$ & $2007^{\mathrm{b}}$ & $1985-89$ \\
\hline Medicine & $\begin{array}{l}\text { Discovery of odorant receptors and the } \\
\text { organization of the olfactory system }\end{array}$ & $5,230,508$ & $9,906,471$ & $2004^{\mathrm{b}}$ & $1985-91$ \\
\hline
\end{tabular}

Source: ${ }^{a}$ History of Radio Astronomy in Cambridge, https://www.astro.phy.cam.ac.uk/about/history/history-1.

${ }^{\mathrm{b}}$ National Institutes of Health (NIH) Report, https://report.nih.gov/.

*The funding data obtained from NIH Report starting in 1985.

Table 2. Some typical big science projects with big costs

\begin{tabular}{|c|c|c|c|}
\hline Field: Aim & Representative project (period) & $\begin{array}{c}\text { Initial budget/US \$ billion } \\
\text { (converted to } 2019 \text { US\$ billion) }\end{array}$ & $\begin{array}{l}\text { Cumulative cost/ US \$ billion } \\
\text { (converted to } 2019 \text { US \$ billion) }\end{array}$ \\
\hline Physics: Atomic bomb & Manhattan (1942-46) & $0.000006(*)^{\mathrm{a}}$ & $2(2)^{\mathrm{a}}$ \\
\hline Physics: Finding Higgs & LHC (1984-2012) & $7.5 €(10.52)^{\mathrm{b}}$ & 4.332 $\mathrm{CHF}(4.3)^{\mathrm{c}}$ \\
\hline Aerospace: Moon landing & Apollo (1960-72) & $19.9(114.19)^{\mathrm{d}}$ & $25.4(105.53)^{\mathrm{e}}$ \\
\hline Astronomy: Exploring cosmos & Hubble (1977-2020) & $0.036(0.113)^{\mathrm{f}}$ & $2(11.697)^{\mathrm{g}}$ \\
\hline Biology: Exploring life & HGP (1990-2003) & $0.013(0.0256)^{\mathrm{h}}$ & $5(5.087)^{\mathrm{i}}$ \\
\hline
\end{tabular}

Source: ${ }^{a}$ Encyclopedia Britannica, https://www.britannica.com/event/Manhattan-Project.

${ }^{\mathrm{b}}$ Wikipedia contributors, https://en.wikipedia.org/wiki/Large Hadron Collider\#cite note-67.

${ }^{\mathrm{c}}$ Facts and figures about LHC, CERN, https://home.cern/resources/faqs/facts-and-figures-about-lhc.

${ }^{\mathrm{d}}$ The Apollo Spacecraft: A Chronology, volumes I through IV, https://history.nasa.gov/SP-4029/Apollo_18-16_Apollo_Program_Budget_Appropriations.htm.

${ }^{\mathrm{e}} 1974$ NASA authorization hearings, https://babel.hathitrust.org/cgi/pt?id=mdp.39015084762718\&view=1up\&seq=1277.

${ }^{\mathrm{f}}$ History of the Space Telescope, http://articles.adsabs.harvard.edu/pdf/1979QJRAS..20...29S

${ }^{g}$ NASA James Webb Report, https://www.nasa.gov/pdf/499224main JWST-ICRP Report-FINAL.pdf.

${ }^{\mathrm{h}}$ Nature, https://www.nature.com/articles/455876a.

${ }^{\mathrm{i}}$ Nature, https://www.nature.com/articles/d41586-018-07323-y.

the new political economy of science produced by World War II, during which the US Government funded huge research efforts such as the Manhattan Project. Not only did Weinberg describe a new way of organizing scientific research, but his concept expressed nostalgia for 'little science', which is a world of individual researchers who have the freedom to carry out their research.

Big science is a scientific research model that emerged during and especially after the World War II (ref. 7). It is characterized by the use of large instruments or facilities, and the mobilization of financial and human support from national governments or international organizations with costs ranging between US\$ 5 and 10 billion. The most famous big science projects include the Apollo Project, CERN's Large Hadron Collider (LHC) and Hubble Space Telescope, among others. Certainly, big investments have generated great achievements (Table 2).

The representative examples in Table 2 suggest that the investments in big science projects are at the magnitude of billion dollars, in which only the finding of the Higgs boson in LHC led to a Nobel Prize.

\section{Big science with big issues: socio-economic problems beyond science}

At its best, science is a human endeavour with a superhuman aim: the discovery of regularities in the order of nature, and the discerning the consequences of those regularities.

The research mode of big science is different from that of small science. According to Alberts ${ }^{8}$, 'Big Science style of research continues to sweep the headlines'. Big science thrives on publicity; so the injection of a journalistic flavour into big science is inevitable, which is fundamentally in conflict with the scientific method ${ }^{9}$.

Big science not only means big budget, but also big laboratories, big research groups and a big bureaucracy. Leaders of such big science projects have to spend their time finding and accounting for funds and dealing with various organizational matters instead of thinking about the projects themselves ${ }^{9,10}$. Weinberg mentioned in 1961: 'Unfortunately, science dominated by administrators is science understood by administrators, and such science 
quickly becomes attenuated if not meaningless.' Scientists working on big science projects are most likely to lose autonomy and just follow the instruction of project leaders, which may stifle the creativity of scientists and do great harm to fundamental scientific paradigms. Price ${ }^{1}$ also mentioned that many participants of big science projects have seen their creativity restrained, because such projects often have an unshakable goal. On the contrary, small science projects often engage scientists on individual curiosity-driven work, which may lead to genuine scientific findings ${ }^{11}$.

Big science can be divided into two types: one exploring the unknown world, such as Hubble and Human Genome Project (HGP), which expands human knowledge; the other aiming for concrete goals, such as the explosion of an atomic bomb in the Manhattan Project and landing human beings on the moon through the Apollo project. The groundwork of big science projects often comes from small science ${ }^{6}$. The second type of big science projects sometimes is just superposition of known technologies; as such they are essentially engineering and technical in nature and tend to achieve goals of national missions and public policy goals contributing not much new knowledge.

Although some big science projects such as the Apollo moon landing and Hubble telescope were relatively successful, there have also been examples of unsuccessful big science projects, such as the war on cancer. Big science projects may fail for being guided by problematic theories with dark matter detection being one such exam$\mathrm{ple}^{12}$. Therefore, the initiation of big science projects that consume a lot of funds and resources should be based on the consultation with multiple stakeholders (especially those showing no interests) before making prudent decisions.

A typical example of failed big science projects is the Super Superconducting Collider (SSC). As early as 1987, the Nobel laureate Steven Weinberg led the construction of an SSC in the US, hoping to knock out supersymmetric particles and verify the theory of supersymmetry. It was claimed that the SSC would be able to help humans solve the origin of the universe and fulfil the dream of the ultimate theory of physics. Initially, Weinberg proposed not so small a budget of US\$ 4.4 billion. However, six years later, in 1993, when the project only completed the tunnel installation of the collider, the cost had already climbed to nearly US $\$ 2$ billion. The overall budget could have been as much as US\$ 10 billion. Finally, the US Congress cancelled the project after several rounds of hearing ${ }^{13}$.

Although big science projects are valuable to human progress, their possible negative impacts on the scientific and socio-economic development cannot be neglected. Stifling the creativity of scientists, inefficiency, failure in expanding human knowledge, and breaking the balance of resources diverted from the economy and society have caused problems to science and beyond ${ }^{8-10}$. Therefore, a holistic perspective is needed to consider both science (big or small) and its social impact (big or small) (Figure 1). Policymakers have to consider the implications of any decision in science.

\section{Cost-benefit analysis: a comparison of $\mathrm{LHC}$ and CNAO projects}

The growth of scientific research has exceeded public resources available so the most effective allocation of limited resources has become a concern of governments ${ }^{14}$. Only the impact on academia and scientific knowledge was noticed in the past ${ }^{15}$. For instance, health research is oriented towards improving health of the public. However, evaluation of this kind of research was only limited to the quality of science rather than the impact on health, which is unreasonable ${ }^{16}$. In fact, the social impact of research is not only limited to knowledge output (direct impact), but also spillovers (indirect impact), such as competencies, technologies, instruments, networks and problem-solving ability ${ }^{17}$. Indirect impact is more difficult to measure than direct scientific impact which can be measured by publications; the former may emerge after many years ${ }^{14}$ and so econometric studies, survey and case studies are the main approaches ${ }^{17}$.

Figure 1 would direct the policymakers to consider two important dimensions when deciding to invest in science projects (small or big). The scale is seen as the cost and the social impact is regarded as benefit of science. Costbenefit analysis (CBA) is an appropriate quantitative method to calculate investment and social impact of research projects.

There are many different CBA frameworks, but most of them are only for small science or there are few indicators to a project's measured social impacts ${ }^{18-20}$. However, Florio and Sirtori ${ }^{21}$ developed an application of the CBA framework, which can be used in evaluating big or small science projects. In particular, this framework contains six indicators about direct and indirect benefits and five indicators about costs ${ }^{21,22}$ :

(1) Knowledge output $(S)$ : this is related to new knowledge, generally in publications.

(2) Technological spillovers $(T)$ : knowledge promotes technological development, which benefits firms.

(3) Human capital formation $(H)$ : students and professionals obtain training and educational benefits.

(4) Cultural effects $(C)$ : this relates to public benefits, such as disseminating scientific knowledge through conferences, events and visits.

(5) Benefits of applied research to external users or other consumers $(A)$.

(6) Non-use (existence) benefits $\left(B_{\mathrm{n}}\right)$ : future possible effects or pure public good. 


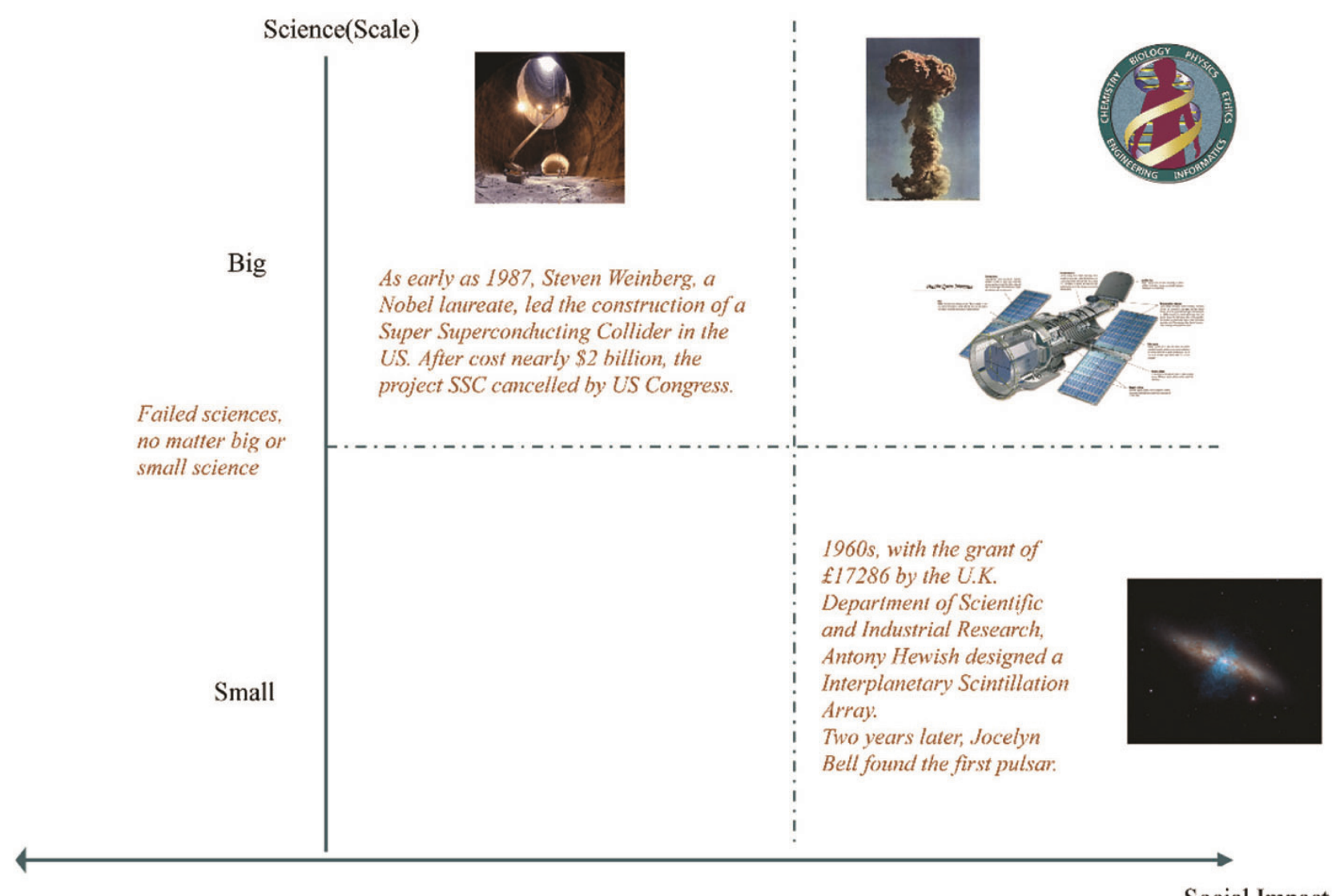

Negative Impact

Small

Big

Figure 1. Science versus social impact: a holistic perspective.

The costs include the economic value of capital $(K)$, labour cost of scientists $\left(L_{\mathrm{s}}\right)$ and other administrative and technical staff $\left(L_{\mathrm{o}}\right)$, other operating costs $(O)$ and negative externalities $(E)$.

The formula of net present value (NPV) is

$$
\begin{aligned}
\mathrm{NPV}= & \left(S+T+H+C+A+B_{\mathrm{n}}\right) \\
& -\left(K+L_{\mathrm{s}}+L_{\mathrm{o}}+O+E\right) .
\end{aligned}
$$

The framework has been used in the assessment of two projects-CERN's LHC and hadrontherapy at the National Hadrontherapy Centre for Cancer Treatment (CNAO) in Italy $^{23}$. Both of them use the same equipment, the particle accelerator, but the former focuses on the fundamental problems of physics, while the latter uses it in medicine. Hence, it is reasonable to compare these two projects ${ }^{24}$. Authors adopt different ways to collect data about the cost and benefit, such as archival records, scientific publications and interviews. The LHC study calculated costs and benefits from 1993 to 2015, while the CNAO study computed the same from 2002 to 2031 . A probability distribution function (PDF) was used to forecast future costs and benefits based on the sample information or expert assessment $^{22}$. Table 3 shows the costs and benefits of these two projects.

From Table 3, we can see that the total cost of LHC is US\$ 13.5 billion, which is different from that in Table 2. The reason is that the total cost includes not only funding, but also labour cost, negative externalities and so on. The total cost of CNAO is US\$ 465.9 million including funding and other costs. Based on the conclusion of Table 1, the funding of CNAO is in millions of US dollars, so CNAO belongs to medium or small science.

Although LHC has higher benefits, the benefit/cost ratio of CNAO is about four times that of $\mathrm{LHC}$. The top two benefits of LHC are human capital formation and technological spillovers, which mainly benefit researchers and firms. Although scientists won the Nobel Prize for their discovery of the Higgs boson, a new particle, this is a discovery coming from this long-term and expensive project; so the benefit of knowledge output is low relative to its cost. As an applied research project, CNAO generated less knowledge output but benefits the public enormously, as cancer patients can get more advanced treatment.

CEPC under consideration in China is not only more efficient and expensive than LHC, but its probability of 
Table 3. The cost-benefit data of LHC and CNAO

\begin{tabular}{|c|c|c|c|c|}
\hline & \multicolumn{2}{|c|}{ LHC } & \multicolumn{2}{|c|}{ CNAO } \\
\hline & $\begin{array}{c}\text { Value } \\
\text { (billion euro) }\end{array}$ & $\begin{array}{l}\text { Share of total } \\
(\%)\end{array}$ & $\begin{array}{c}\text { Value } \\
\text { (million euro) }\end{array}$ & $\begin{array}{c}\text { Share of total } \\
(\%)\end{array}$ \\
\hline Total costs & 13.5 & 100 & 465.9 & 100 \\
\hline Total benefits & 16.377 & 100 & 2058.9 & 100 \\
\hline Knowledge output & 0.277 & 1.69 & 11.7 & 0.57 \\
\hline Technological spillovers & 5.3 & 32.36 & 22.4 & 1.08 \\
\hline Human capital formation & 5.5 & 33.58 & 15.4 & 0.75 \\
\hline Cultural effects & 2.1 & 12.82 & 6.1 & 0.30 \\
\hline $\begin{array}{l}\text { Benefits of applied research to external users } \\
\text { or other consumers }\end{array}$ & 0 & 0 & 2003.3 & 97.2 \\
\hline Non-use benefits & 3.2 & 19.54 & 0 & 0 \\
\hline Benefit/cost ratio & 1.21 & - & 4.42 & - \\
\hline
\end{tabular}

Data from refs $22-24$

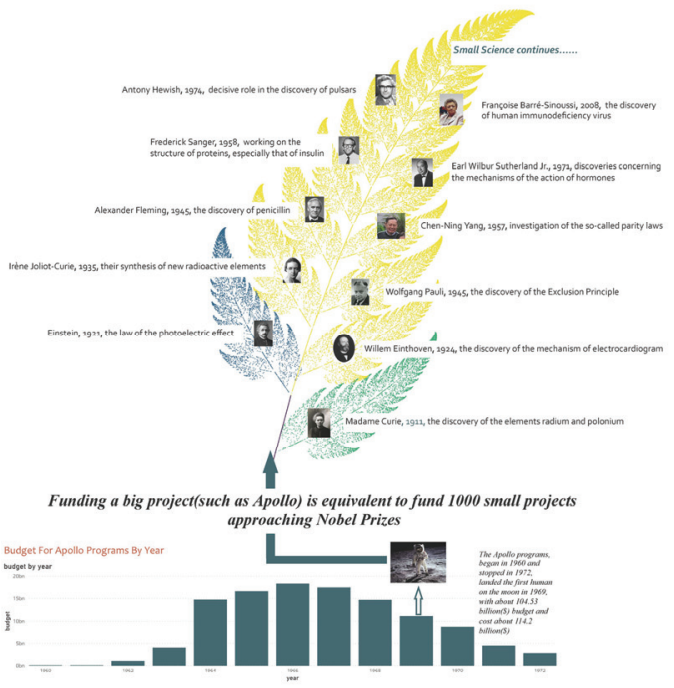

Past

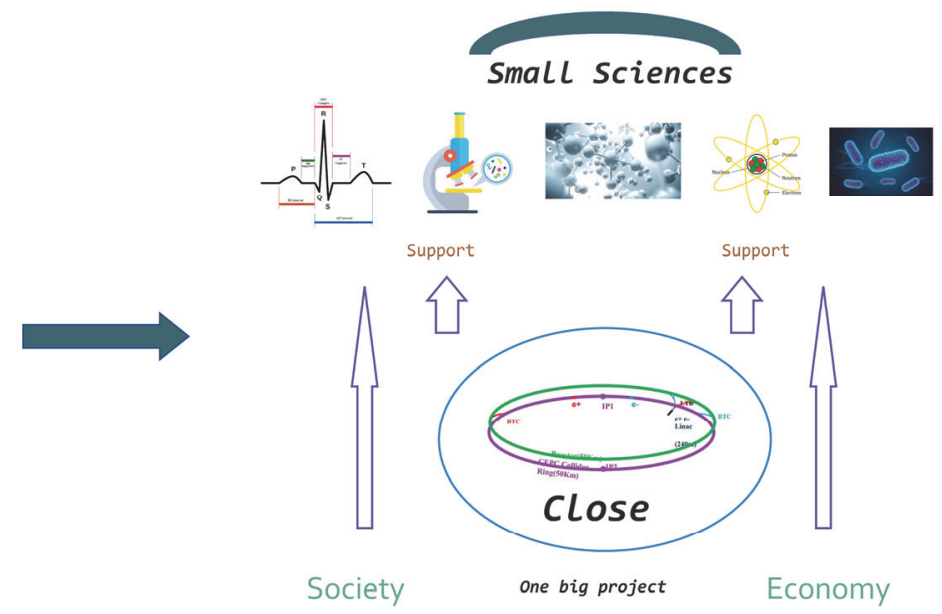

Present

Figure 2. Close one big science project to support 1000 smaller ones.

finding new particles seems to be low. Since CEPC is similar to LHC, perhaps the top benefits of CEPC are still technological spillovers and human capital formation. This result is inconsistent with the original goal of government funding, that is, scientific discovery. Nevertheless, there are many small science projects in artificial intelligence and molecular biology, for example, which are more likely to produce great achievements, and these projects tend to score higher on knowledge output. In addition, the above comparison shows that such livelihood projects as CANO deserve more attention, because their benefits far outweigh their costs ${ }^{25}$.

Despite some defects in these two studies, such as data collection and lack of environmental impact assessment, this framework can be adopted ${ }^{24}$. Based on the above structured discussion, we may conclude that in the case of limited research funding, governments should be inclined to invest in 1000 small projects that are more likely to achieve breakthroughs or benefit the public at large, rather than one big project.

\section{Policy implications and discussion}

While big science consumes socio-economic resources at the level of billions of US dollars, small science needs investments only at the level of millions of US dollars. Moreover, large teams develop and small teams disrupt science $^{12}$. Although big science projects also have spillover effects affecting the development of directly or indirectly related scientific fields and industries and creating employment opportunities, small science yields more genuine findings. Therefore, the questions posed by big science are not confined to science itself, but need to be tackled with a multidimensional approach dealing with issues related to society and the economy. Using the budget of 
one big science project for 1000 small science projects, we may come up with more scientific discoveries or more benefits to the public at large. For effectively balancing scientific cognition and socio-economic development, three policy effects may be considered. (1) Funding any big science project should consider both scientific issues and socio-economic values. At least, a cost-benefit comparison in scientific research should be taken into account. (2) Small science projects could be more effective than big science projects in scientific exploration. Since many problems in the world and the universe are still unknown to us, we need to meet grand scientific challenges rather than big science projects. (3) Replacing big science with many small science projects might benefit scientific discoveries. Perhaps, small science projects will be important for more real scientific discoveries.

Figure 2 shows that following historical experiences, we can equivalently support 1000 small science projects if we close one big science project.

In a word, big science entails not only a scientific issue, but also a socio-economic problem, and more than that. The huge consumption of funding and resources needs a reasonable interpretation that everyone understands. Such a rationale is also applicable to China's CEPC. As German theoretical physicist Sabine Hossenfelder ${ }^{26}$ lamented recently, the world does not need a new gigantic particle collider, but true scientific discoveries.

Competing interests: The authors declare no competing interests.

1. Price, D. J., Little Science, Big Science... and Beyond, Columbia University Press, New York, 1986.

2. Penrose, R., The Road to Reality: A Complete Guide to the Laws of the Universe, Jonathan Cape, London, 2004.

3. Gibney, E., Inside the plans for Chinese mega-collider that will dwarf the LHC. Nature, 2018.

4. Group CEPCP-DS, The CEPC input for the European Strategy for Particle Physics - Physics and Detector, 2019.

5. Group TCEPCAS, The CEPC input for the European Strategy for Particle Physics - Accelerator, 2019.

6. Berg, J., Science, big and small. Science, 2017, 358, 1504.

7. Dennis M. A., Big science. Encyclopedia Britannica, Encyclopedia Britannica, Inc, 2017.

8. Alberts, B., The end of 'small science'? Science, 2012, 337, 1583.

9. Weinberg, A. M., Impact of large-scale science on the United States. Science, 1961, 134, 161-164.

10. Alberts, B. M., Limits to growth: in biology, small science is good science. Cell, 1985, 41, 337-338.

11. Goldstein, J. L. and Brown, M. S., A golden era of Nobel laureates. Science, 2012, 338, 1033-1034.
12. Wu, L., Wang, D. and Evans, J. A., Large teams develop and small teams disrupt science and technology. Nature, 2019, 566, 378-382.

13. Frenkel, K. A., Nobelist Steven Weinberg Calls for Bigger Science, More Taxes, 2011.

14. Bornmann, L., Measuring the societal impact of research. Embo Rep., 2012, 13, 673-676.

15. Bornmann, L., What is societal impact of research and how can it be assessed? A literature survey. J. Am. Soc. Inform. Sci. Technol., 2012, 64, 217-233.

16. Smith, R., Measuring the social impact of research - difficult but necessary. Br. Med. J., 2001, 323, 528.

17. Salter, A. J. and Martin, B. R., The economic benefits of publicly funded basic research: a critical review. Res. Policy, 2001, 30, 509-532.

18. Gaughan, P., Hallinan, D. and Reilly, K., Using economic cost benefit analysis methodologies to underpin the sustainability and strategic planning of coastal ocean research infrastructures in Europe. In OCEANS - Marseille Conference, Marseille, France, 2019.

19. Sheth, A. and Sarkar, D., Social benefit cost analysis of electric bus transit for Ahmedabad. Trans. Dev. Econ., 2021, 7, 6; https:// doi.org/10.1007/s40890-021-00116-5.

20. Poder, T. G., Erraji, J., Coulibaly, L. P. and Koffi, K., Percutaneous coronary intervention with second-generation drug-eluting stent versus bare-metal stent: Systematic review and cost-benefit analysis. PLoS ONE, 2017, 12, e0177476; https://doi.org/10.1371/ journal.pone. 0177476 .

21. Florio, M. and Sirtori, E., Social benefits and costs of large scale research infrastructures. Technol. Forecast. Social Change, 2016, 112, 65-78.

22. Florio, M., Forte, S. and Sirtori, E., Forecasting the socio-economic impact of the Large Hadron Collider: a cost-benefit analysis to 2025 and beyond. Technol. Forecast. Soc. Change, 2016, 112, $38-53$.

23. Battistoni, G. et al., Cost-benefit analysis of applied research infrastructure. Evidence from health care. Technol. Forecast. Soc. Change, 2016, 112, 79-91.

24. Magazinik, A. et al., Societal impact as cost-benefit analysis: comparative analysis of two research infrastructures. In 2019 IEEE International Conference on Engineering, Technology and Innovation (ICE/ITMC). IEEE, France, 2019.

25. Frank, C. et al., Health research: measuring the social, health and economic benefits. Can. Med. Assoc. J., 2009, 180, 528-534.

26. Hossenfelder, S., The world doesn't need a new gigantic particle collider. Sci. Am., 2020.

ACKNOWLEDGEMENT. We acknowledge financial support from the National Natural Science Foundation of China Grant numbers 71673131 and 71774091

Received 19 September 2020; revised accepted 28 June 2021

doi: $10.18520 / \mathrm{cs} / \mathrm{v} 121 / \mathrm{i} 4 / 479-484$ 